\title{
Deterioration of Teak Wood in Accelerated Decay Test
}

\author{
Weslley Candido de Oliveira ${ }^{1}$ (D), Bárbara Luísa Corradi Pereira ${ }^{1}$ (D), \\ Leonora Stéfani de Assis Goes ${ }^{1}$ (D), Manolo Trindade Quintilhan ${ }^{2}$ (D), \\ Aylson Costa Oliveira ${ }^{1}$ (D), Rômulo Môra ${ }^{1}$ \\ ${ }^{1}$ Faculdade de Engenharia Florestal, Universidade Federal de Mato Grosso - UFMT, Cuiabá/MT, Brasil \\ ${ }^{2}$ Departamento de Ciências Florestais, Escola Superior de Agricultura "Luiz de Queiroz" - ESALQ, Universidade de \\ São Paulo - USP, Piracicaba/SP, Brasil
}

\begin{abstract}
The present study aimed to evaluate the biological resistance of teak (Tectona grandis) heartwood and sapwood to the action of Trametes versicolor and Gloeophyllum trabeum fungi in laboratory accelerated decay assays. The mass loss evaluation of the samples was performed periodically. The heartwood presented a higher percentage of extractives and the sapwood of holocelluloses. The sapwood and heartwood subjected to the fungus Gloephyllum trabeum remained stable. For the Trametes versicolor fungus, there was an increasing loss of mass over time for both regions, presenting a mass loss of $40 \%$ for the sapwood and of $20 \%$ for the heartwood at the conclusion of the assay. Teak wood was classified as highly resistant to the fungus Gloeophyllum trabeum, and moderately resistant to Trametes versicolor.
\end{abstract}

Keywords: tectona grandis, natural durability, biological test. 


\section{INTRODUCTION}

Wood is subject to decay due to biological organisms that break it down to use its constituents as energy source, acting together with physical, chemical and mechanical agents that accelerate the decaying process (Vivian et al., 2015). The agents responsible for the majority of damage caused to wood are biological, with fungi, mainly from the Basidiomicetos class (Paes et al., 2007), being most prominent. Within this class, the brown and white rot fungi stand out. Both present specific enzymatic characteristics in relation to the decay of primary wood constituents, generally affecting mechanical resistance and physical properties (Oliveira et al., 2005).

Tectona grandis L.f., commonly known as teak, is a large size tree, native to tropical forests of Asian origin, mainly found in India, Burma and Thailand (Pelissari et al., 2013). It is one of the preferred species for reforestation and for solid and laminated wood products (Motta et al., 2013). Its high value and importance are attributed to its desirable physicalmechanical properties, as well as its robustness and vigorous development (Flórez et al., 2014).

Studies related to the natural durability of wood are indispensable to provide a better quality final product, generating information regarding its use in situations of exposure to bio-deteriorating agents and to reduce costs. Modes et al. (2012) argues that this information can permit rationalized wood use, as well as a better prediction regarding its behavior under diverse conditions.

When considering that the species that present greater natural durability originate in tropical forests, the use of species from passively planted forests with preservative treatment becomes a promising alternative. In field trials, it is possible to reproduce the situations for wood use with or without chemical treatment. In this condition, the wood is exposed to irregular light, leaching and drought cycles, as well as to chemical and physical agents in the soil, and diverse xylophagous agents that act together. However, there are certain difficulties when conducting these field assays, being the main one the long period (years) necessary to realize the analysis.

Therefore the use of laboratory decay assays with small sized pieces provides information related to the natural resistance of the wood over a shorter period (months). Stangerlin (2012) highlights that the application of these assays has been used with the objective of assisting in the first stage for the qualification of the natural durability of wood, aiming to meet the immediate requirements for economic and technological sectors.

Therefore, the objective of the present study was to evaluate the natural resistance of teak wood originating from the heartwood and sapwood regions to the action of Trametes versicolor and Gloeophyllum trabeum fungi in accelerated, laboratory decay assays.

\section{MATERIAL AND METHODS}

\subsection{Collection of material}

Teak wood (Tectona grandis L.f.) was collected from a settlement in the municipality of Tangará da Serra, Mato Grosso state. The average age of the plantation was 6 years. The selected trees were collected and transformed into 5-cm thick discs.

Sapwood and heartwood proof bodies were produced from the discs, with dimensions of $2.5 \times 2.5 \times 0.9 \mathrm{~cm}$ (radial $\times$ tangential $\times$ longitudinal) in the Laboratory of Wood Technology of the Faculty of Forestry Engineering at the Universidade Federal de Mato Grosso (UFMT), Cuiabá Campus. These were sanded, numbered and dried in a hothouse at a temperature of $103 \pm 2{ }^{\circ} \mathrm{C}$ until reaching constant mass, which was determined using scales of $0.0001 \mathrm{~g}$ precision.

\subsection{Preparation of xylophagous fungi}

Two species of xylophagous fungi were used, obtained from the Laboratory of Forestry Products of the Brazilian Forestry Service located in Brasilia, DF: Trametes versicolor (Linnaeus ex Fries) Pilat, the species that causes white rot; and Gloeophyllum trabeum (Persoon. ex Fries.) Murr., the species that causes brown rot.

Ten Petri dishes were inoculated for each fungal species. The inoculation was of a sample of about $1 \mathrm{~cm}$ diameter containing the mycelium of the fungus, taken from a mother-dish younger than 3 months old and maintained under refrigeration. After inoculation, the dishes were placed in the incubator for 30 days for mycelium growth. Subsequently, for each fungal 
species, 4 dishes with good growth were selected to act as an inoculant source for the cultures in solid medium.

The culture medium was prepared with Potato, Dextrose and Agar (PDA) medium, prepared with $200 \mathrm{~g}$ of potato, $10 \mathrm{~g}$ of Agar and 1 liter of distilled water. Twenty-four Petri dishes were prepared, 12 for each fungus. These were sterilized at $121^{\circ} \mathrm{C}$ for 15 minutes to avoid contamination; $12 \mathrm{~mL}$ of culture medium were added to each dish. After preparation, they were conditioned for 15 days at a temperature of $27 \pm 2{ }^{\circ} \mathrm{C}$.

\subsection{Installation of the experiment}

For the laboratory decay assays, $200 \mathrm{~mL}$ flasks with a threaded plastic lid were used. To prepare the assay, $70 \mathrm{~g}$ of red latosol soil were added to each flask, collected from the experimental farm of the Universidade Federal de Mato Grosso located in the municipality of Santo Antônio do Leverger, Mato Grosso state. Microorganisms tend to develop in more or less low $\mathrm{pH}$ environments. Therefore, to avoid the development of other fungi, limestone was previously added to the soil to elevate the $\mathrm{pH}$ to 6.5 , and it was stored for drying at room temperature. The addition of $20 \mathrm{~mL}$ of distilled water was necessary to adjust the humidity to approximately $130 \%$ of its water retention capacity as established by the American Society for Testing and Materials - ASTM D-2017 (ASTM, 2005).

For the initial development of the fungi, support discs of susceptible woods were produced with dimensions of $0.3 \times 3.0 \times 3.0$ (thickness $\times$ length $\times$ width). Pinus (Pinus sp.) support discs were used for the growth of G. trabeum; and balsa wood (Ochroma pyramidale) for the T. versicolor.

The flasks were sterilized for one hour in an autoclave at $121^{\circ} \mathrm{C}$ to eliminate the existing agents. One $\mathrm{mL}$ of culture medium containing fragmented fungal mycelium was inoculated into each flask, depositing a part over the wooden disc and another part over the soil. After inoculation, the flasks were returned for incubation for a period of 30 days, the time necessary for the fungal mycelium to homogenously cover the substrate surface.

After colonization of the support dishes, a proof body (heartwood or sapwood) was placed into each flask on the support disc, remaining incubated in contact with the fungus for a period of 12 weeks, according to the study developed by Stangerlin (2012), at a temperature of $27 \pm 2{ }^{\circ} \mathrm{C}$ and a humidity of $65 \pm 5 \%$. All manipulation operations of the fungus were performed under aseptic conditions.

Sixteen pinus (Pinus sp.) samples were used as reference species for the fungus $G$. trabeum, and 16 balsa wood (Ichroma pyramidale) samples for the T. versicolor. The reference samples are indicators of vegetative vigor of the fungal culture used in the experiment, and for the incubation conditions according to ASTM D-2017 (ASTM, 2005).

Periodical evaluations at 21, 42, 63 and 84 days were realized, totaling four over the twelve-week assay period. After removing the flasks from the incubator, the samples were cleaned and dried in a hothouse at a temperature of $103 \pm 2{ }^{\circ} \mathrm{C}$ for $24 \mathrm{~h}$ to achieve constant mass, and weighed once again on a $0.0001 \mathrm{~g}$ precision scale to determine final mass.

The evaluation of individual mass loss was performed based on the initial and final mass values for each sample and classified into resistance classes according to the ASTM D-2017 (ASTM, 2005), presented in Table 1.

\subsection{Chemical and apparent density analyses of wood}

The residues generated in the production of the wood samples used were transformed into sawdust in a Willey type mill with a $0.5 \mathrm{~cm}$ sieve. Based on the material retained between the 40 and 60 mesh sieves,

Table 1. Classification of natural resistance of wood subjected to xylophagous fungal attack.

\begin{tabular}{ccc} 
Mean mass loss (\%) & Mean residual mass (\%) & Resistance class \\
0 to 10 & 90 to 100 & Very resistant \\
11 to 24 & 76 to 89 & Resistant \\
25 to 44 & 56 to 75 & Moderately resistant \\
45 or more & 55 or less & Little resistance or non- resistant \\
\hline
\end{tabular}

Source: ASTM D-2017 (ASTM, 2005). 
the chemical analyses for lignin, holocellulose and total extractives levels were performed.

To determine the total extractives, the Technical Association of the Pulp and Paper Industry norms TAPPI $264 \mathrm{~cm}$-97 (TAPPI, 1997) - were used for the substitution of the ethanol/benzene solution with ethanol/toluene. Were used $2.0 \mathrm{~g}$ of sawdust samples completely dried, placed into sintered glass filters of porosity 2 , inserted into a Soxhlet extractor for extraction in ethanol/toluene for $5 \mathrm{~h}$, absolute ethanol for $4 \mathrm{~h}$, and subsequently in hot water for $1 \mathrm{~h}$. After extraction, the material was placed in a hothouse maintained at a temperature of $103 \pm 2{ }^{\circ} \mathrm{C}$ and its mass was determined using a $0.0001 \mathrm{~g}$ precision scale. The extractives level was calculated based on dry mass before and after extraction.

The insoluble lignin content in wood was determined using the Klason method modified by Gomide \& Demuner (1986). The soluble lignin was determined by spectrometry, according to Goldschmid (1971). Acid hydrolysis was performed with $72 \%$ sulfuric acid on $0.3 \mathrm{~g}$ of sawdust free of extractives at $30{ }^{\circ} \mathrm{C}$ for $1 \mathrm{~h}$. Subsequently, the mixture was diluted to $3 \%$ and subjected to another hydrolysis at a pressure of $2.0 \mathrm{~atm}$ and $121^{\circ} \mathrm{C}$ for $1 \mathrm{~h}$. The insoluble lignin levels were determined using filtration, and the soluble lignin levels using spectrometry. The total lignin levels were obtained using the sum of the insoluble and soluble lignins. The holocellulose, cellulose sum and hemicelluloses levels were estimated, taking from 100 the lignin and total extractives levels.
The apparent wood density was determined according to the Brazilian Regulatory Norms - NBR 7190 of the Brazilian Association of Technical Norms (ABNT, 1997), being defined as the ratio between the mass and volumes of the samples with humidity levels at $12 \%$. The sample densities were evaluated before and after fungal action.

\subsection{Statistical analysis}

The treatments were distributed into an entirely randomized design, in subdivided parcels, with wood type (heartwood or sapwood) into the parcels, the fungal type into the sub-parcels, (Trametes Versicolor and Gloeophyllum trabeum), and the decay time into the sub-parcels (21, 42, 63 and 84 days), with three repetitions.

The tests for normality of data and homogeneity of variance were performed, establishing the significant differences. The results were submitted to analysis of variance, realizing the necessary elaborations, with the treatments compared to each other using the Tukey test $(\mathrm{p}<0.05 \%)$.

\section{RESULTS AND DISCUSSION}

\subsection{Decay in laboratory}

There was significant interaction between the different treatments (Table 2). The interactions were performed and the means compared using the adopted means test. The analyses of the results are presented in Tables 2, 3, 4, 5 and 6.

Table 2. Analysis of variance for the mass loss of Tectona grandis subjected to accelerated.

\begin{tabular}{|c|c|c|c|c|}
\hline Variation sources & $\begin{array}{l}\text { Degree of } \\
\text { freedom }\end{array}$ & Sum of squares & Squared means & F - calculated \\
\hline Treatment - a (Wood) & 1 & 792.3500 & 792.3500 & $263.2057 * *$ \\
\hline Residue - a & 4 & 12.0415 & 3.0103 & \\
\hline Parcels & 5 & 804.3915 & & \\
\hline Treatment - b (Fungus) & 1 & $2,511.4133$ & $2,511.4133$ & $806.1039^{* *}$ \\
\hline Int. $(\mathrm{a} \times \mathrm{b})$ & 1 & 694.7930 & 694.7930 & $233.0120^{\star *}$ \\
\hline Residue - b & 4 & 12.4619 & 3.1155 & \\
\hline Sub-parcels & 11 & $4,023.0598$ & & \\
\hline Treatment - c (Time) & 3 & $1,166.1878$ & 388.7292 & $61.6344^{* *}$ \\
\hline Int. $(\mathrm{a} \times \mathrm{c})$ & 3 & 107.5490 & 35.8497 & $5.6841^{\star *}$ \\
\hline Int. $(b \times c)$ & 3 & $1,051.4751$ & 350.4917 & $55.5717^{\star *}$ \\
\hline Int. $(\mathrm{a} \times \mathrm{b} \times \mathrm{c})$ & 3 & 99.6768 & 33.2256 & $5.2680^{* *}$ \\
\hline Residue - c & 24 & 151.3648 & 6.3070 & \\
\hline Total & 47 & $6,599.3172$ & & \\
\hline
\end{tabular}

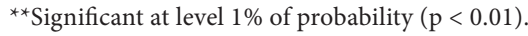


Table 3. Mean values of mass loss for Tectona grandis wood according to the types of wood and fungus.

\begin{tabular}{ccc} 
Wood & $\begin{array}{c}\text { Trametes } \\
\text { versicolor }\end{array}$ & $\begin{array}{c}\text { Gloeophyllum } \\
\text { trabeum }\end{array}$ \\
\hline Sapwood & $40.80 \mathrm{aA}$ & $2.23 \mathrm{aB}$ \\
Heartwood & $18.90 \mathrm{bA}$ & $1.72 \mathrm{aB}$ \\
\hline
\end{tabular}

Means followed by the same upper case letter horizontally or lower case letter vertically, do not differ by Tukey test $(\mathrm{p}>0.05)$.

Table 4. Mean mass loss values for Tectona grandis wood according to wood types and time of evaluation.

\begin{tabular}{ccccc}
\multirow{2}{*}{ Wood } & \multicolumn{4}{c}{ Time (days) } \\
\cline { 2 - 5 } & $\mathbf{2 1}$ & $\mathbf{4 2}$ & $\mathbf{6 3}$ & $\mathbf{8 4}$ \\
\hline Sapwood & $4.43 \mathrm{aD}$ & $10.94 \mathrm{aC}$ & $16.18 \mathrm{aB}$ & $21.54 \mathrm{aA}$ \\
\hline Heartwood & $1.21 \mathrm{bB}$ & $2.45 \mathrm{bB}$ & $6.57 \mathrm{bA}$ & $10.35 \mathrm{bA}$ \\
\hline
\end{tabular}

Means followed by the same upper case letter horizontally or lower case letter vertically, did not differ by Tukey test $(\mathrm{p}>0.05)$.

Table 5. Mean values of mass loss for Tectona grandis wood as a function of fungus type and time.

\begin{tabular}{ccccc} 
& \multicolumn{4}{c}{ Time (days) } \\
\cline { 2 - 5 } Fungus & $\mathbf{2 1}$ & $\mathbf{4 2}$ & $\mathbf{6 3}$ & $\mathbf{8 4}$ \\
\hline $\begin{array}{c}\text { Trametes } \\
\text { versicolor }\end{array}$ & $4.30 \mathrm{aD}$ & $11.33 \mathrm{aC}$ & $20.25 \mathrm{aB}$ & $29.89 \mathrm{aA}$ \\
$\begin{array}{c}\text { Gloeophyllum } \\
\text { trabeum }\end{array}$ & $1.34 \mathrm{bA}$ & $2.07 \mathrm{bA}$ & $2.50 \mathrm{bA}$ & $2.00 \mathrm{bA}$ \\
\hline
\end{tabular}

Means followed by the same upper case letter horizontally or lower case vertically, did not differ by Tukey test $(\mathrm{p}>0.05)$.

Table 6. Mean values of mass loss for Tectona grandis wood as a function of fungi at the end of the experiment.

\begin{tabular}{|cccc|}
\hline Wood & Fungus & $\begin{array}{c}\text { Mass loss } \\
(\%)\end{array}$ & $\begin{array}{c}\text { Resistance } \\
\text { class }\end{array}$ \\
\hline Sapwood & T. versicolor & $40.8 \mathrm{a}$ & $\begin{array}{c}\text { Moderately } \\
\text { resistance }\end{array}$ \\
\hline Heartwood & T. versicolor & $18.9 \mathrm{~b}$ & Resistant \\
\hline Sapwood & G. trabeum & $2.27 \mathrm{c}$ & Very Resistant \\
\hline Heartwood & G. trabeum & $1.73 \mathrm{c}$ & Very Resistant \\
\hline
\end{tabular}

Means followed by the same letter on the vertical, did not differ according to the Tukey test $(\mathrm{p}>0.05)$.

The vegetative vigor of the fungi was determined by the decay of $65 \%$ of the average residual mass of the balsa wood for T. versicolor and $63 \%$ of the pinus wood for G. trabeum.

The values observed (Table 3) show that the fungi tested do not attack the wood with the same intensity, with the T. versicolor fungus generally being more aggressive than G. trabeum for the wood regions evaluated (heartwood and sapwood).
For mass loss, when analyzing the effect of the fungi on the trunk region, it was found that T. versicolor caused greater mass loss both in heartwood and sapwood. In contact with the G. trabeum fungus, teak wood did not present significant mass loss for either heartwood or sapwood.

These results agree with Vivian et al. (2015), who found greater average mass loss generated by T. versicolor ( $47.9 \%$ sapwood and $16.6 \%$ heartwood) in comparison with G. trabeum (32.3\% sapwood and $7.87 \%$ heartwood) when testing two Eucalyptus sp., wood species. Carneiro et al. (2008), testing for the natural durability of Amazonian woods, observed similar values for mass loss for the Virola caducifólia species (41.4\%) and Trattinnickia rhoifolia (37.1\%) under action of T. versicolor, both species of hardwood like teak. Stangerlin et al. (2013) found mass loss values for T. versicolor of $64.7 \%$ and $48.7 \%$ for marupá and jequitiba from Amazônia, respectively.

For heartwood and sapwood subjected to action of the fungus G. trabeum, there was no notable mass loss, with the fungus presenting low development. Similarly, Bhat et al. (2005) obtained average mass loss values of $9 \%$ for sapwood and $2.33 \%$ for heartwood when evaluating approximately 35 -year old teak. Oliveira et al. (2005) also found a lower average mass loss percentage for G. trabeum, in which the woods of all the species were found to be resistant, presenting an average mass loss lower than 10\% for seven Eucalyptus species under xylophagous fungal action.

When analyzing the behavior of teak heartwood and sapwood after each evaluation, (Table 4), an increase in mean mass loss with increasing of time of exposure to fungi and greater decay was observed for sapwood, which also presented greater susceptibility to attack during all periods evaluated. The heartwood presented a certain resistance during initial evaluations ( 21 and 42 days) with very low mass loss values, presenting a small variation after the 42 -day period assay, being more noticeable at the end of the experiment.

For all the evaluations over time, the sapwood presented greater mass loss when compared to heartwood. Paes et al. (2007) observed greater resistance for teak sapwood (25.2\%) under xylophagous fungal action over a 98-day assay. Motta et al. (2013) also observed greater mass loss for teak sapwood (25.04\%) 
of approximately 15 years under xylophagous fungal action over 13 weeks.

When analyzing wood decay provoked by exposure time to fungi (Table 5), there was greater mass loss for all the evaluations in which the wood was in contact with $T$. versicolor fungi, which presented good development from the beginning to the end of the assay, with mass loss values increasing at each evaluation. Teak wood presented good resistance to the action of G. trabeum fungus, with the results being similar for all the evaluations, that is, mass loss was low and stable. Alves et al. (2006) observed periods in which the growth of $G$. trabeum fungus remained stable, showing slower development in comparison with white rot fungi.

Torelli \& Cufar (1994), when evaluating the natural resistance of 43 hardwood species, observed that T. versicolor generated greater mass loss than G. trabeum. Therefore, it can be observed that xylophagous fungi can present distinct wood decay characteristics depending on the forest species. Schmidt (2006) argues that the different needs and physiological characteristics of the fungi lead to preferences for some woods according to their chemical composition.

According to the ASTM D-2017 (ASTM, 2005) (Table 1), it was possible to classify the wood in classes of natural resistance to xylophagous organisms (Table 6), in which sapwood was classified as having moderate biological resistance to the T. versicolor fungus. The same classification was given by Paes et al. (2007) for teak wood, when evaluating the resistance of four species naturally occurring in the semiarid zones and three acclimatized exotic species, and by Vivian et al. (015) in hardwood under T. versicolor action.

Sapwood was classified as very resistant to G. trabeum action. In studies conducted in laboratory with six eucalypt species subjected to G. trabeum fungus, Oliveira et al. (2005) observed high resistance, with mean mass loss values of around 3\% for all woods.
This was due to the white rot fungi developing better in hardwood, while the brown rot fungi caused greater mass loss in conifer wood (Martínez et al., 2005).

Heartwood presented good resistance to both fungi. Under T. versicolor action, the wood was classified as resistant. For G. trabeum, heartwood was classified as very resistant. Similar results were observed by Paes et al. (2007), who classified teak heartwood as very resistant to white and brown rot fungi (Postia placenta and Polyporus fumosus). Clausen (2010) classified teak heartwood as very resistant to decay from xylophagous fungi.

When heartwood was subjected to fungi attack, it was observed lower mass loss than with sapwood. Similar results were observed by Paes et al. (2007) for wood resistance to xylophagous fungi, observing that heartwood of nearly all the species presented greater resistance to decay compared with sapwood when subjected to conditions favorable to decay.

\subsection{Chemical analysis of wood}

To better understand which wood constituent decayed more, chemical characterization of wood was performed (Table 7). Generally, higher extractive levels were observed in the heartwood region. Holocellulose was greater in the sapwood. There was no notable difference in lignin content.

One of the main factors affecting natural resistance of wood is the difference in the extractives present, being these found in greater quantities in the heartwood region. The sapwood is more susceptible to decay due to being part of the wood that presents stored nutritive material (Motta et al., 2013). Therefore, it is possible to observe that independent of the fungus, the heartwood region presented greater natural resistance due to possessing greater extractive levels. There is a direct relation between the extractive levels and the natural resistance potential (Carneiro et al., 2008). Stangerlin (2012) highlighted that normally, woods

Table 7. Chemical composition of sapwood and heartwood of Tectona grandis.

\begin{tabular}{cccc} 
Material & $\begin{array}{c}\text { Total Lignin } \\
(\%)\end{array}$ & Total Extractives (\%) & $\begin{array}{c}\text { Holocelluloses } \\
(\%)\end{array}$ \\
\hline Sapwood & $32.42 \mathrm{a}$ & $4.89 \mathrm{~b}$ & $62.69 \mathrm{a}$ \\
\hline Heartwood & $32.87 \mathrm{a}$ & $7.18 \mathrm{a}$ & $59.95 \mathrm{~b}$ \\
\hline
\end{tabular}

Means followed by the same letter in the column do not differ according to the Tukey test $(p>0.05)$. 
Table 8. Mean values of apparent density loss for Tectona grandis wood as a function of fungi.

\begin{tabular}{ccccc} 
Material & Fungus & $\begin{array}{c}\text { Initial density } \\
\left(\mathbf{g} / \mathbf{~ m}^{-3}\right)\end{array}$ & $\begin{array}{c}\text { Final density } \\
\left(\mathbf{g} / \mathbf{m}^{-3}\right)\end{array}$ & Density loss $(\%)$ \\
\multirow{2}{*}{ Sapwood } & T. versicolor & $0.47 \mathrm{a}$ & $0.24 \mathrm{~b}$ & 48.9 \\
& G. trabeum & $0.48 \mathrm{a}$ & $0.42 \mathrm{~b}$ & 12.5 \\
\multirow{2}{*}{ Heartwood } & T. versicolor & $0.50 \mathrm{a}$ & $0.37 \mathrm{~b}$ & 26.1 \\
& G. trabeum & $0.52 \mathrm{a}$ & $0.46 \mathrm{~b}$ & 11.5 \\
\hline
\end{tabular}

Means followed by the same letter on the horizontal do not differ by the Tukey test $(p>0.05)$.

from the Amazon region have extractive levels greater than $7 \%$, possess a high natural resistance potential and consequently decay is minimized.

According to Motta et al. (2013), durability of teak wood in the heartwood region is caused by the presence of tectoquinone. This is due to a quantity of extractives being deposited in the heartwood cells when losing physiological function, which can be toxic in the specific case of the fungi, hampering hypha development and decomposing enzyme action (Paes et al., 2007).

Sapwood presents greater holocellulose levels because it is the part of the tree that contains live and physiologically active cells, serving as a food reserve, containing more starch and participating in the conduction functions of the plant. This makes it more susceptible to attack by xylophagous organisms (Moya et al., 2012). The low resistance of sapwood is observed in practically all species, and its useful life is generally short under conditions favorable to decay (Clausen, 2010).

Teak wood presents very close lignin quantities between the heartwood and sapwood regions. Chagas et al. (2014) observed similar values for the lignin percentage for 4, 6 and 12-year old teak (30.28, 30.17 and 30.43\% respectively).

\subsection{Apparent density}

For both fungi, a significant loss of density was reported in terms of the means before and after exposure to fungi. The most significant reduction was observed in wood in contact with the fungus T. versicolor, with the highest values reported in the sapwood region (Table 8). In wood subjected to G. trabeum, there was less reduction of density, with the values for sapwood and heartwood being similar. Generally, we can say that there was a proportional relation between wood density and the resistance to the fungi tested, in which the heartwood region, which presented greater density, was more resistant. Stallbaun et al. (2016) also observed this relation when studying Tachigali vulgaris species under the action of xylophagous fungi.

Santos et al. (2011) and Arantes et al. (2016) affirmed that density is one of the most common parameters to express wood quality due to its easy determination, and for being related to the other wood properties.

\section{CONCLUSIONS}

Teak wood presents high biological resistance to Gloeophyllum trabeum fungus, both in heartwood and sapwood regions.

For the fungus Trametes versicolor, the sapwood was classified as having moderate biological resistance, while the heartwood was classified as resistant.

\section{ACKNOWLEDGEMENTS}

To my mother Rosicler Dias Gomes. To my advisers Dr. Aylson Costa Oliveira and Dr. Barbara Luísa Corradi Pereira for all the time dedicated me. To the Laboratory of Wood Technology - UFMT, and others involved. To the Faculty of Forestry Engineering of the University of Mato Grosso Cuiabá. To all the people who, in any way, contributed to the accomplishment of this work.

\section{SUBMISSION STATUS}

Received: 22 mar., 2017

Accepted: 27 mar., 2018 


\section{CORRESPONDENCE TO}

\section{Weslley Candido Oliveira}

Universidade Federal de Mato Grosso - UFMT, Av. Fernando Corrêa da Costa, 2367, CEP 78060900, Cuiabá, MT, Brasil

e-mail: wcoflorestal@gmail.com

\section{FINANCIAL SUPPORT}

Conselho Nacional de Desenvolvimento Científico e Tecnológico.

\section{REFERENCES}

Alves MVS, Costa AF, Espig DS, Vale AT. Resistência natural de seis espécies de madeiras da Região Amazônica a fungos apodrecedores, em ensaios de laboratório. Ciência Florestal 2006; 16(1): 17-26. http://dx.doi. org/10.5902/198050981884.

American Society for Testing and Materials - ASTM. ASTM: D - 2017: Standard method for accelerated laboratory test of natural decay resistance for woods. West Conshohocken: ASTM; 2005. 5 p.

Arantes MDC, Trugilho PF, Tomazello M Fo, Lima JT. Densitometria de raios X na madeira e carvão de clone de Eucalyptus grandis W. Hill ex Maiden X Eucalyptus urophylla S. T. Blake. Revista Árvore 2016; 40(1): 155-162. http://dx.doi.org/10.1590/0100-67622016000100017.

Associação Brasileira de Normas Técnicas - ABNT. NBR 7190: Projeto de estruturas de madeira. Rio de Janeiro: ABNT; 1997. 107 p.

Bhat KM, Thulasidas PK, Florence EJ, Jayaraman K. Wood durability of home-guarden teak against brown-rot and white-rot fungi. Tress 2005; 19(6): 654-660. http:// dx.doi.org/10.1007/s00468-005-0429-0.

Carneiro JS, Emmert L, Sternad GH, Mendes JC, Almeida GF. Decay susceptibility of Amazon wood species from Brazil against white rot and brown rot decay fungi. Holzforschung 2008; 63: 767-772.

Chagas SF, Evangelista WV, Silva JC, Carvalho AMML. Propriedades da madeira de teca de diferentes idades e oriundas de desbaste. Ciência da Madeira 2014; 5(2): 138-150.

Clausen CA. Biodeterioration of wood. In: United States Department of Agricutlure-USDA. Wood handbook: wood as an engineering material. 100th ed. Madison: USDA, Forest Service, Forest Products Laboratory; 2010. 16 p. (General Technical Report FPL-GTR 190).

Flórez JB, Trugilho PF, Lima JT, Hein PRG, Silva JRM. Caracterización de la madera joven de Tectona grandis
L. f. plantada en Brasil. Madera y Bosques 2014; 20(1): 11-20. http://dx.doi.org/10.21829/myb.2014.201172.

Goldschmid O. Ultraviolet spectra. In: Sarkanen KV, Ludwig CH, editors. Lignins: occurrence, formation, structure and reactions. New York: Wiley-Interscience; 1971. p. 241-266.

Gomide JL, Demuner BJ. Determinação do teor de lignina na madeira: método Klason modificado. O Papel 1986; 47(1): 36-38.

Martínez AT, Speranza M, Ruiz-Dueñas FJ, Ferreira P, Camarero S, Guillén F et al. Biodegradation of lingo cellulosics: microbial, chemical, and enzymatic aspects of the fungal attack of lignin. International Microbiology 2005; 8(3): 195-204. PMid:16200498.

Modes KS, Lazarotto M, Beltrame R, Vivian MA, Santini JE, Muniz MFB. Resistência natural das madeiras de sete espécies florestais ao fungo Pycnoporus sanguineus causador da podridão branca. Cerne 2012; 18(3): 407-411. http://dx.doi.org/10.1590/S0104-77602012000300007.

Motta PM, Oliveira JTS, Paes JB, Alves RC, Dambroz GBV. Resistência natural da madeira de Tectona grandis em ensaio de laboratório. Ciência Rural 2013; 43(8): 1393-1398. http://dx.doi.org/10.1590/S0103-84782013005000097.

Moya R, Fallas RS, Bonilla PJ, Tenorio C. Relationship between wood color parameters measured by the CIELab system and extractive and phenol content in Acacia mangium and Vochysia guatemalensis from fast-growth plantations. Molecules (Basel, Switzerland) 2012; 17(4): 3639-3652. http://dx.doi.org/10.3390/molecules17043639. PMid:22450677.

Oliveira JT, Tomasello M Fo, Silva JC. Resistência natural da madeira de sete espécies de eucalipto ao apodrecimento. Revista Árvore 2005; 29(6): 993-998. http://dx.doi.org/10.1590/S0100-67622005000600019.

Paes JB, Melo RR, Lima CR. Resistência natural de madeiras a fungos xilófago em condições de laboratório. Revista de Ciências Agrárias (Belém) 2007; 47: 199-210.

Pelissari AL, Caldeira SF, Drescher R. Desenvolvimento quantitativo e qualitativo de Tectona grandis L.f. em Mato Grosso. Floresta e Ambiente 2013; 20(3): 371-383.

Santos RC, Carneiro ACO, Mendes AFN, Castro RVO, Souza MM, Cardoso MT. Correlações entre os parâmetros de qualidade da madeira e do carvão vegetal de clones de eucalipto. Scientia Forestalis 2011; 39: 39-46.

Schmidt O. Wood and tree fungi: biology, damage, protection, and use. Berlin: Springer-Verlag; 2006. 334 p.

Stallbaun PH, Baraúna EEP, Monteiro TC, Vieira RS, Sales NLP, Oliveira LS. Resistência natural da madeira de Tachigali vulgaris ao fungo xilófago Postia placenta. Pesquisa Florestal Brasileira 2016; 88(36): 459-463.

Stangerlin DM, Costa AF, Garlet A, Pastore TCM. Resistência natural da madeira de três espécies amazônicas submetidas ao ataque de fungos apodrecedores. 
Ciência da Madeira 2013; 4(1): 15-32. http://dx.doi. org/10.12953/2177-6830.v04n01a02.

Stangerlin DM. Monitoramento de propriedades de madeiras da amazônia submetidas ao ataque de fungos apodrecedores [tese]. Brasília: Universidade de Brasília; 2012.

Technical Association of the Pulp and Paper Industry - TAPPI. TAPPI test methods: T $264 \mathrm{~cm}-97$ : preparation of wood for chemical analysis. Atlanta: Tappi Technical Dovisions and Committees; 1997.
Torelli N, Cufar K. Comparative decay resistance of 43 Mexican tropical hardwoods. Holz als Roh- und Werkstoff 1994; 52(6): 394-396. http://dx.doi.org/10.1007/ BF02615392.

Vivian AM, Santini JE, Modes KS, Garlet A, Morais WWC. Resistência biológica da madeira tratada de Eucalyptus grandis e Eucalyptus cloeziana a fungos apodrecedores em ensaios de laboratório. Ciência Florestal 2015; 1: 175-183. 